\title{
Practical Dimension and Optimization Strategy of Improving the Teaching Quality of Political Theory Courses in Colleges and Universities
}

\author{
Xiaojian Xu \\ School of Marxism, Qufu Normal University, Rizhao, Shandong, China
}

\begin{abstract}
It is the fundamental task of the political theory courses in colleges and universities to cultivate the builders and successors of the socialist cause. Because the teaching of political theory courses plays an important role in casting souls and educating people. Therefore, teachers should focus on enhancing the dissemination, theory and pertinence of ideological and political teaching in the process of carrying out political theory courses teaching practice, and make great efforts in the theory, content and methods of political theory courses teaching in order to continuously improve the teaching quality of political theory courses. Make the political theory courses truly recognized by the majority of young students. From the perspective of "teaching" and "learning", the improvement of political theory teaching quality in colleges and universities can be considered from three practical dimensions: curriculum cognition, goal orientation and teaching resources.
\end{abstract}

Key words: political theory courses; teaching quality; practical dimension; general outlook of history

\section{Introduction}

Political theory courses in colleges and universities, as the main courses to implement the fundamental tasks of moral education, are the main positions to inherit red genes and cultivate a team of young students with excellent political qualities. For a long time, in the teaching practice of political theory courses in colleges and universities, there are many problems, such as insufficient attention, nonstandard teaching organization and implementation, imperfect quality evaluation system and so on. How to further improve the teaching quality of political theory courses in colleges and universities is particularly necessary. In fact, the improvement of the teaching quality of political theory courses in colleges and universities is not simply a process of transforming theories into stories, but is directly related to students' awareness of the courses and their learning purposes. Therefore,It is necessary to explore how to effectively improve the teaching quality of political theory courses in colleges and universities from three practical dimensions: curriculum cognition, goal orientation and teaching resources. Taking the course "Introduction to Mao Zedong Thought and the Theoretical System of Socialism with Chinese Characteristics" (the "introduction course") as an example, this study focuses on analyzing the effective ways to improve the teaching quality of political theory courses, and explores the main paths for innovative development of political theory courses.

Copyright $(\mathcal{C} 2021$ by author(s) and Frontier Scientific Research Publishing Inc.

This work is licensed under the Creative Commons Attribution International License (CC BY 4.0). http://creativecommons.org/licenses/by/4.0/ 


\section{Curriculum Cognitive Dimension}

Clarifying the nature and characteristics of a course is an important way to improve the teaching quality of political theory courses, because the choice of teaching resources needs to be based on the nature and characteristics of the course, and the nature and characteristics of the course are the first part of students' preliminary understanding of the knowledge system of the course. In addition, defining the cognitive dimension of the course is also an important premise and basis for determining the goal-oriented dimension and teaching resource dimension of the course.

\subsection{Clear the nature of political theory courses}

Clarifying the nature of a course can not only increase students' understanding and grasp of the course system, but also help students to clarify the training goal, course orientation and teaching purpose of political theory courses, thus continuously strengthening students' cognitive system and learning purpose. Political theory courses to colleges and universities is a political philosophy about the development of modern China. The so-called political philosophy is the knowledge of governing the country and safeguarding the state. This course mainly studies the basic laws and experiences of the new-democratic revolution, socialist revolution, socialist construction and reform under the leadership of the Communist Party of China. When introducing the nature of political theory courses, teachers should emphasize that the course is the product of combining Marxism with Chinese practice.

\subsection{Clear the basic characteristics of political theory courses}

The special nature of a course often determines its basic characteristics. Generally speaking, the basic characteristics of the "introduction course" include the following aspects. First of all, it is necessary to clarify the scientific nature of the course. Some people think that political ideas can often deny its scientific nature, which is actually a cognitive fallacy. If it is not scientific, it will lose its root and cannot convince people. It can't be transformed into great material power, so its life will be terminated, and such theoretical content will not play much role in guiding practice. Secondly, we should make clear the discipline of the "introduction course". Teachers of political theory courses should make students understand that this is a science or discipline. It is a true knowledge and discipline about the development of modern China. In addition, we should make clear the political nature of the "introduction course". As a science of national governance, since it can govern the country well, there is no reason to manage an organization or enterprise badly, or even to manage a family or individual's life badly, because people share the same heart and mind. The ways of governance are all interlinked. Only in this way can students deeply realize that this course has great political value and significance for the way of politics and the pursuit of real life.

In addition, the "introduction course" also has theoretical characteristics. Deepening the research on the key and difficult problems in the teaching of political theory education is the key link to improve the quality of political theory courses in colleges and universities. Generally speaking, the outline course pays more attention to historical logic, while the "introduction course" pays more attention to theoretical logic and practical logic besides historical logic. Therefore, this requires teachers to grasp the content system of the "introduction course" as a whole from three aspects: historical logic, theoretical logic and practical logic, and constantly raise the teaching content to the level of theoretical exploration.

\section{Goal Oriented Dimension}

It is very important to clarify the teaching goal orientation of a course. From the perspective of teachers' teaching, the setting of curriculum goal orientation dimension will affect the teaching goal, teaching method and teaching effect of this course. From the perspective of students' learning, the curriculum goal-oriented dimension will be related to students' learning goals, learning attitudes, learning motivation, even the learning effect. 


\subsection{Guide students to establish correct learning goals}

The learning attitude of a course affects the learning effect of the course There have always been two kinds of attitudes towards learning, that is, the attitude of learning for the sake of academics, which holds that there is no utilitarian purpose in learning, but this attitude certainly has merits. Because the true meaning of learning is to pursue the truth and seek the truth, but it also has certain limitations. If learning can not be combined with some major issues such as real society and real life, its vitality will be limited. The other is the attitude of learning for life, which holds that learning should serve the real society and life. Academic research should be closely related to today's major practical problems, so that it can really show its strong vitality. This is the fine study style of Chinese tradition, but we should also be alert to the tendency of pragmatism to make quick profits and instant benefits. Teachers should learn to combine the pursuit of truth and truth with serving the society and life effectively in the teaching of the "introduction course".

3.2 Clearly set up the main purpose of the "introduction course"

Defining the purpose of a course is the key to learning it well. First of all, we should pay attention to improving the knowledge structure in the study of knowledge of "introduction course". Because it is about the historical laws and theories of modern China's development, which involves a wide range of contents, including the knowledge of politics, military affairs, diplomacy, economy, culture and ecology in modern China. It is necessary for students to understand that learning "introduction course" well will help to further improve and expand students' knowledge structure, and provide the premise and foundation for understanding and thinking in future study. Secondly, the "introduction course" also pays attention to enhance students' cognition and judgment ability. Through the study and research of this course, students can have a better understanding of national history and national conditions, and also help them pass on the mainstream thoughts, national spirit and core values of our country to students, understand the macro trend of national and social development, and deeply realize that the fate of the country is closely related to the fate of each individual. In addition, by studying the "introduction course", teachers should make students realize that they can continuously enhance their political theoretical accomplishment, cultivate their political consciousness and leadership ability, in order to be the qualified citizens and successors of modernization.

The above contents are all from the perspective of students' individual development. In addition, teachers should learn to guide students to make clear the main purpose and the importance of offering an "introduction course" from the perspective of the state and society. The importance is directly related to the cultural security of our country, and the purpose is to distinguish right from wrong on the theoretical level, maintain a certain strength, and firmly grasp the correct direction of progress on the principle of right and wrong, so as to make due contributions to the modernization cause.

3.3 Clarify the logical relationship of "three whys"

"Three whys" is actually a scientific answer to three basic questions: "Why can the Communist Party of China", "Why is socialism with Chinese characteristics good" and "Why does Marxism work". Therefore, we can clarify the theoretical connotation and internal logical relationship of these three problems in theory, make students clearly understand the inevitability of "why can we succeed", thus further strengthening students' "four matters of confidence". When teachers think about how to answer the basic question of "three whys" in the teaching process, they can't carry out theoretical analysis in isolation. It is necessary to combine some important historical facts and historical context to elaborate their mutual relations. In addition, students should be fully aware of the basic problem of "three whys", and its internal logic is a progressive relationship. The key for teachers to answer the basic question of "three whys" in lectures lies in whether they can explain clearly the internal logical relationship among them. Finally, teachers can also integrate the basic questions of "three whys" into the learning clues and the explanation of knowledge system of the teaching materials of "introduction 
course", so as to clarify the related contents of the corresponding logical starting point, logical center of gravity and logical end point.

\section{Dimension of Teaching Resources}

Teaching resources selected according to teaching objectives and students' individualized needs and development are effective ways to improve teaching quality. Teaching resources should not be limited to teaching materials, but should be close to students' daily study and life, and should pay attention to the needs of the times of national and social development. Therefore, during the teaching practice of "introduction course", appropriate teaching resources should be selected from three angles of the country, society and students' development.

4.1 Fully integrate the educational resources of the histories of the Communist Party of China, New China, the reform and opening-up, and socialist development into the process of telling the content of teaching materials

The educational resources of the histories of the Communist Party of China, New China, the reform and opening-up, and socialist development are the powerful guarantee and important content of enhancing students' cultural self-confidence, and the basic historical experience of the histories of the Communist Party of China, New China, the reform and openingup, and socialist development is also the deep foundation of enhancing students' "four matters of confidence". Therefore, teachers should learn to guide students to be good at summing up historical experience and development rules in learning the histories of the Communist Party of China, New China, the reform and opening-up, and socialist development, and constantly carry forward the national spirit and the spirit of the times.The main purpose is to enhance students' cultural self-confidence. The importance of the histories of the Communist Party of China, New China, the reform and opening-up, and socialist development education shows that only by analyzing historical phenomena and exploring the understanding of the Communist Party of China's ruling law and construction law in the long history, can we profoundly reveal the historical roots of the Chinese nation's great leap from standing up, becoming rich to becoming strong. Teachers should pay attention to the following points in the process of carrying out the histories of the Communist Party of China, New China, the reform and opening-up, and socialist development education.

Firstly, they need to guide students to deeply realize the great practical significance of studying the histories of the Communist Party of China, New China, the reform and opening-up, and socialist development. Secondly, they should actively guide students to learn from the Communist Party of China's fine style and carry forward the great revolutionary spirit. Finally, they should guide students to strengthen theoretical research, straighten out the logic of the histories of the Communist Party of China, New China, the reform and opening-up, and socialist development and tell Chinese stories well. On this basis, teachers should guide students to establish the correct learning purpose and attitude of learning history, enhancing trust, respecting morality and practicing history, actively guide students to remember the course of the Party's struggle by studying the histories of the Communist Party of China, New China, the reform and opening-up, and socialist development, further strengthen students' responsibility and mission, and constantly draw forward strength from the history of the Party's struggle.

4.2 Tell the historical logic of the content of political theory teaching resources from the perspective of general outlook of history

The general outlook of history emphasizes the logic of historical development, pays attention to the context and continuity of historical development. Instead of talking about an era around it, it advocates that the historical facts of an era should be examined in the process of historical development of human society. When teachers of political theory courses state historical background, historical facts and historical events, we can make full use of the general outlook of history to tell its ins and outs, organically combine the past, present and future of the development of things from the time dimension 
according to historical logic, especially in the "introduction course" class, and we should dynamically analyze specific events in the context of the evolution of Chinese civilization and the historical changes of human society. By analyzing the historical logic of events, we can not only effectively sum up the relevant historical experience, but also further obtain the corresponding historical enlightenment. In addition, teachers of political theory courses should learn to profoundly reveal the historical inevitability of choosing the road of socialism with Chinese characteristics with a great view of history. It profoundly reveals major practical issues such as the process of global modernization, the evolution of international pattern, and the relationship between China and the world powers.

Telling the "introduction course" with general outlook of history should also pay attention to exploring the historical law of events, and avoid the phenomenon of telling history in terms of history. Teachers should avoid fragmentation when telling the details of some historical research results. In fact, the "introduction course" with the great view of history is not just a textual research on specific historical events, but should learn from history. Emphasize historical laws, pay attention to historical experience and historical enlightenment.

\section{Conclusions}

To sum up, from the perspective of curriculum cognition, teachers should guide students to clarify the nature and basic characteristics of the course in the process of carrying out the teaching practice of political theory courses in colleges and universities. Only by clarifying the nature and basic characteristics of the "introduction course", students can quickly form a cognitive understanding of the course, so as to lay a foundation for teachers to explain the course knowledge system in the future and make students have a better grasp of the learning clues of this course. In addition, teachers should also make clear the importance of goal-oriented dimension in the process of carrying out political theory teaching practice. From the perspective of goal orientation, teachers should learn to guide students to set up correct learning goals, clarify the main purpose of offering "introduction course", and clarify the logical relationship of "three whys". Only by establishing a correct orientation of curriculum objectives on the political theory level of students, can we further stimulate and guide students to form a scientific curriculum knowledge system and truly implement the fundamental task of cultivating people by virtue. Finally, from the perspective of teaching resources, teachers should learn to fully integrate the educational resources of the histories of the Communist Party of China, New China, the reform and opening-up, and socialist development into the process of telling the content of teaching materials. Teachers need to tell the historical logic of the content of political theory teaching resources from the perspective of general outlook of history. Only by forming various teaching resources or teaching contents, can students form their interest and enthusiasm in learning this course and get rid of their resistance to the theoretical knowledge of this course.

\section{Conflicts of Interest}

The author declares no conflicts of interest regarding the publication of this paper.

\section{References}

[1] Yang J.X, Zhong K.D., Zhou Q. (2021). Exploring the Focus Teaching Mode of Ideological and Political Courses in Colleges and Universities in the New Era from the Perspective of Education Empowerment. Journal of Zhengzhou University (Philosophy and Social Sciences Edition), (02):27.

[2] Song Y.W., Wang Y. (2018). Deepening the Study of Key and Difficult Problems in Ideological and Political Teaching. China Higher Education, (10):47.

[3] Lu K.M., Peng L. (2020). To Promote the Innovative Development of Ideological and Political Courses, We Should Handle Four Pairs of Relations. China Higher Education, (24):35. 